\title{
FORMULASI SEDIAAN MASKER WAJAH MENGGUNAKAN EKSTRAK ETANOL BUNGA KECOMBRANG (ETLINGERA ELATIOR) TERHADAP KELEMBABAN KULIT WAJAH
}

\author{
${ }^{1}$ Chandra Pranata, ${ }^{2}$ Novidawati Boru Situmorang, ${ }^{3}$ Romauli Anna Teresia \\ Marbun \\ Institut Kesehatan Medistra Lubuk Pakam \\ email: ccandraprnt@gmail.com \\ DOI : https://doi.org/10.35451/jfm.v2i2.364
}

\begin{abstract}
Skin is an essential and vital organ and a reflection of health. Natural antioxidants such as flavonoids, polyphenols and Sapponin are believed to increase moisture on the skin. This ability is the main reason for using Torch Ginger flower extract which is formulated into a form of facial mask in the form of clay facial mask. Objective: To formulate facial moisturizing mask preparations using the extract of Torch Ginger (Etlingera elatior). This study used the Torch Ginger Flower extract facial moisturizing mask formulation method with a concentration of 0 (Blank), 5\% and $10 \%$. Evaluation of mask preparations included homogeneity, stability of dosage at temperatures of $80 \mathrm{C}$ and 250C, Organoleptic test and $\mathrm{pH}$ of preparations. Measurements of skin moisture activity were measured using alar Skin Analyzer which was tested on the face surface $3 \mathrm{~cm}$ wide. The results showed that the preparation was stable in terms of odor, color and was at a pH of 4.2-6.3 using observations of litmus discoloration. Effectiveness of facial skin moisture with $10 \%$ Torch Ginger extract concentration is more effective to produce results at a concentration of 5\% and blank. Conclusion: Torch Ginger flower extract can be formulated into preparations of face masks with various concentrations and has the effect of moisturizing the skin and brightening the complexion.
\end{abstract}

Keywords: Torch Ginger Flower Extract, Facial Mask, Clay Facial Mask, Facial Skin Moisture

\section{PENDAHULUAN}

Kulit merupakan organ yang esensial dan vital serta merupakan cerminan kesehatan. Kulit terletak paling luar dan membatasi dengan lingkungan hidup Manusia. Kulit adalah organ kompleks yang terlibat dalam pertukaran gas, perlindungan terhadap patogen, dan memiliki fungsi untuk mempertahankan hidrasi. Terdapat tiga lapisan struktur kulit yaitu epidermis, dermis dan subkutis. Rambut, kuku, kelenjar sebasea, kelenjar keringat dan Apokrin dianggap sebagai derivat dari kulit. Kulit adalah organ dinamis yang secara konstan berubah, sel pada lapisan luar berganti secara terus menerus dan digantikan oleh selsel dari dalam yang naik ke permukaan. Perawatan kulit dapat dilakukan dengan 2 cara yaitu dengan cara pencegahan (preventive) yang dilakukan sebelum terjadinya kelainan dan perbaikan (corrective) yang umumnya dilakukan setelah timbul kelainan, misalnya alergi terhadap kosmetika yang dipakai. Untuk perawatan secara preventif diperlukan kosmetika berupa pembersih (susu pembersih, face tonic), pelembab, 
Received: 30 Maret 2020 :: Accepted: 29 April 2019 :: Published: 30 April 2020

pelindung kulit (tabir surya dan alas bedak), dan penipis kulit ( peeling powder, scrub cream, dan masker). Sedangkan perawatan korektif atau perbaikan bisa dilakukan dengan cara alat Mikrodermabrasi. Tumbuhan Kecombrang (Etlingera elatior) merupakan salah satu jenis tanaman rempah-rempah asli Indonesia yang termasuk dalam Familia Zingiberaceae yang secara tradisional sudah lama digunakan dan dimanfaatkan masyarakat

Sebagai obat-obatan dan penyedap rasa (Syarief, 2016). Selain itu, Kecombrang juga disebutkan sebagai tanaman multiguna karena dari semua bagian tanaman dapat digunakan sebagai sesuatu yang bermanfaat. Secara umum Kecombrang digunakan untuk mengobati campak, penambah darah, Osteoporosis, penambah energi dan mengatasi dehidrasi (Dinkes, 2016). Di Indonesia tanaman jenis rempah ini hampir tersebar di seluruh kawasan Indonesia dan bagian yang digunakan adalah bagian bunga, daun dan batangnya. Pemanfaatannya, tanaman kecombrang dikembangkan melalui penelitian dan dijadikan sebagai obat tradisional karena bunga kecombrang merupakan tanaman yang sangat bermanfaat tetapi belum dikenal secara umum oleh masyarakat (Sanni, 2012)

Banyak Tumbuhan liar dengan sangat mudah ditemukan tetapi belum kenal pemanfaatanya secara luas oleh masyarakat, dapat dibudidayakan menjadi tanaman yang produktif yang memiliki khasiat dan nilai gizi yang sangat baik (Tarmizi, 2010). Penelitian mengenai senyawa bioaktif pada E.elatior pernah dilakukan dengan ekstraksi dan skrining dengan etanol (Jackie, 2011). Selain itu penelitian lain yang pernah dilakukan dalam pemanfaatan kecombrang sebagai formulasi sediaan lipstik pewarna bibir antioksidan yang dalam penguji olesan didapat hasil warna terbaik pada konsentrasi $24 \%$ dengan $\mathrm{pH} 3.8-4.1$ (Adliani 2012). Penelitian lain juga melakukan pengujian efektivitas sediaan salep ekstrak etanol bunga Kecombrang sebagai antibakteri Staphylococcus aureus dengan hasil yang positif bahwa bunga Kecombrang dapat menghambat pertumbuhan bakteri Staphylococcus aureus dengan metode difusi media agar menggunakan kertas cakram Kirby baurer dengan diameter hambat 16.45 $\mathrm{mm}, 18.60 \mathrm{~mm}, 21.12 \mathrm{~mm}$ dengan tiga perlakuan konsentrasi yaitu $100 \mathrm{mg}$, $200 \mathrm{mg}$ dan 300 mg (Debi, 2018). Tanaman Kecombrang mengandung senyawa bioaktif seperti Polifenol, Alkaloid, Flavonoid, Steroid, Sapponin dan minyak atsiri yang diduga memiliki potensi sebagai Antioksidan yang dapat mengurangi radikal bebas, menetralisir racun, dan penyakit genetik (Haraguchi, 1998).

$$
\text { Dalam pengembangannya }
$$

tanaman kecombrang, dibuat suatu formulasi sediaan kosmetik masker pelembab wajah dengan menggunakan bunga Kecombrang (Etlingera elatior) sebagai bahan alami pembuatanannya dengan mempertimbangkan Saat ini dipasaran banyak beredar kosmetik masker wajah yang tebuat dari bahan kimia sintetis yang pada pengunaanya sering kali menimbukan efek negatif pada kulit, salah satu contoh yang dikutip dari jurnal (Firmayanti, dkk 2014) berupa kulir memerah, gatal, dan perih, maka perlu dicari bahan alternatif untuk membuat kosmetik pelembab kulit yang berasal dari alam (Ditjen POM, 1985).

Penggunaan kosmetik dari bahan alami dianggap perlu diterapkan atas dasar perbandingan efek yang ditimbulkan dari keduanya, jika ditinjau dari kedua variable tersebut makan penggunaan kosmetik alami 
Received: 30 Maret 2020 :: Accepted: 29 April 2019 :: Published: 30 April 2020

baik digunakan karena memiliki efek samping yang minim, meminimalisir iritasi pada kulit yang sensitif, ramah lingkungan dan mengandung antioksidan yang tinggi, dalam mendapatkan hasil yang maksimal jika dibandingkan dengan kosmetik disintesis dari segi kekurangannya maka kosmetik sintetis lebih memiliki resiko efek yang besar contohnya menimbulkan bercak pada kulit, alergi, gatal, yang lebih parah bisa menyebabkan kanker Tanaman Kecombrang (Etlingera elatior) adalah salah satu dari banyak jenis tanaman yang memiliki potensi antioksidan alami. Dalam penerapanya ekstraksi senyawa antioksidan dari tanaman umumnya menggunakan jenis pelarut dengan tingkat kepolaran yang berbeda seperti etanol, etil asetat dan n-heksan. Pemilihan pelarut berdasarkan tingkat kepolarannya sangat bermanfaat untuk mendapatkan ekstrak yang lebih besar dan dimaksudkan agar golongan senyawa antioksidan yang memiliki aktivitas tertinggi dapat terekstrak (Lestario et al. 2001).

\section{METODE PENELITIAN}

Metode penelitian ini dilaksanakan secara eksperimen murni dengan teknik Pretest and Posttest Control Group Design. Penelitian meliputi pembuatan sediaan masker wajah ekstrak Bunga Kecombrang. Evaluasi terhadap mutu fisik sediaan seperti uji homogenitas, uji stabilitas sediaan, uji $\mathrm{pH}$ sediaan dan uji efektivitas sediaan sebagai pelembab wajah.

\section{Alat}

Neraca analitik, pH meter, juicer, lumpang, stamfer, objek glass, tutup pot plastik, kain kasa, batang pengaduk, pot plastik dan penangas air (WaterBath).

\section{Bahan}

Bahan-bahan yang digunakan dalam penelitian ini adalah: ekstrak bunga Kecombrang, Bentonite, Xanthan gum, Kaolin, Gliserin, Sodium Lauril Sulfat, Titanium Dioksida, Nipagin, Natrium Metabisulfit, air suling, Metil Biru, larutan dapar pH asam $(4,01)$, larutan dapar $\mathrm{pH}$ netral $(7,01)$.

\section{Sampel Penelitian}

Sampel penelitian berupa bunga Kecombrang yang digunakan sebanyak $5 \mathrm{~kg}$ yang diperoleh dari Lubuk pakam, Pasar rakyat Deli Mas, Kabupaten Deli Serdang.

Cara pembuatan untuk formula basis masker $100 \mathrm{~g}$ yaitu $60 \mathrm{~g}$ aquadest diTuangkan dalam lumpang dan ditambahkan $1 \mathrm{~g}$ bentonite. Bentonite dibiarkan terbasahi lalu ditambahkan $0,8 \mathrm{~g}$ xanthan gum dan digerus cepat sampai seluruh gum melarut. Sebanyak 30,5 g kaolin ditambahkan sedikit demi sedikit dalam lumpang sambil digerus dan ditambahkan 0,5 g $\mathrm{TiO} 2$ dan $2 \mathrm{~g}$ gliserin dalam lumpang. Di samping itu, dilarutkan $0,2 \mathrm{~g}$ natrium metabisulfit dan $0,1 \mathrm{~g}$ nipagin dalam 2,9 g air panas (Larutan A). Larutan A diTuangkan dalam lumpang dan dimasukkan $2 \mathrm{~g}$ sodium lauril sulfat pada lumpang, digerus pelan dan ditambahkan parfum ketika sediaan telah homogen.

\section{HASIL DAN PEMBAHASAN}

Hasil Pengujian Homogenitas

Uji homogenitas dilakukan dengan mengoleskan sediaan pada sekeping kaca atau bahan transparan lain, lalu diratakan, jika tidak ada butiranbutiran maka sediaan dapat dikatakan homogen (Ditjen POM, 1979). Pada sediaan masker wajah yang diformulasi tidak ditemukan adanya butiran kasar dari berbagai 
konsentrasi. Dengan demikian dapat disimpulkan bahwa sediaan masker adalah homogen. Hasil uji homogenitas dapat dilihat pada gambar 1 dibawah ini.

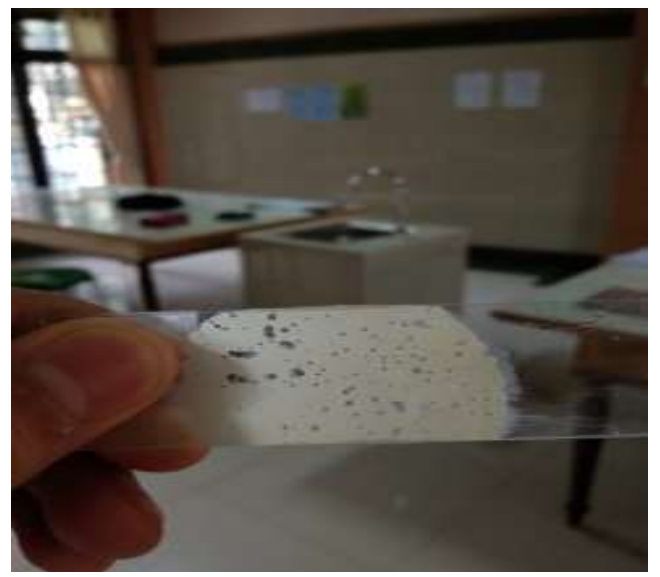

\section{Gambar 1. Uji Homogenitas}

\section{Hasil Pengamatan Stabilitas Sediaan}

Suatu sediaan menjadi tidak stabil akibat penggumpalan dari globul-globul dari fase terdispersi. Rusak atau tidaknya suatu sediaan dapat diamati dengan adanya perubahan bau dan perubahanwarna.Untuk mengatasi kerusakan bahan akibat adanya oksidasi dapat ditambahkan bahan pengawet. Hasil pengamatan stabilitas masing-masing formula yang diatur pada suhu $8^{\circ} \mathrm{C}$ dan $250 \mathrm{C}$ dapat dilihat pada Tabel 1 dan Tabel 2.

Hasil pengamatan stabilitas masingmasing formula yang diatur pada suhu $8^{\circ} \mathrm{C}$ dan $25^{\circ} \mathrm{C}$.

Tabel 1. Pengukuran Pada $\mathrm{pH}$ suhu $80^{\circ} \mathrm{C}$

\begin{tabular}{cccc}
\hline $\mathrm{pH}$ & \multicolumn{3}{c}{ Suhu $80^{\circ} \mathrm{C}$} \\
\cline { 2 - 4 } $\begin{array}{c}\text { Rata- } \\
\text { Rata }\end{array}$ & Blanko & F5\% & $\mathrm{F}$ \\
\multicolumn{1}{c}{ (Hari) } & & & $10 \%$ \\
1 & $4,2-$ & $4,2-$ & $4,2-$ \\
& 6,3 & 6,3 & 6,3 \\
14 & $4,2-$ & $4,2-$ & $4,2-$ \\
\hline
\end{tabular}

\section{$6,3 \quad 6,3 \quad 6,3$}

Tabel 2. Pengukuran Pada $\mathrm{pH}$ suhu $25^{\circ} \mathrm{C}$

\begin{tabular}{clll}
\hline \multirow{2}{*}{$\begin{array}{c}\mathrm{pH} \\
\text { Rata- } \\
\text { Rata }\end{array}$} & \multicolumn{3}{c}{ Suhu $25^{\circ} \mathrm{C}$} \\
\cline { 2 - 4 } (Hari) & nko & F 5\% & F 10\% \\
1 & $4,2-$ & $4,2-$ & $4,2-$ \\
& 6,3 & 6,3 & 6,3 \\
14 & $4,2-$ & $4,2-$ & $4,2-$ \\
& 6,3 & 6,3 & 6,3 \\
\hline
\end{tabular}

\section{Hasil Skrining Fitokimia}

a. Identifikasi Flavonoid

Sebanyak $3 \mathrm{~mL}$ sampel diuapkan, dicuci dengan heksana sampai jernih, residu dilarutkan dalam $20 \mathrm{~mL}$ etanol kemudian disaring. Filtrat dibagi 3 bagian $A, B, C$. Filtrat $A$ sebagai blanko, filtrat $B$ ditambahkan $0,5 \mathrm{~mL} \mathrm{HCL}$ pekat kemudian dipanaskan pada penagas air, jika terjadi perubahan warna Merah Tua sampai Ungu menunjukkan hasil yang positif. Filtrat $C$ ditambahkan 0,5 $\mathrm{mL} \mathrm{HCL}$ dan logam $\mathrm{Mg}$ kemudian diamati perubahan warna yang terjadi. Warna Merah sampai jingga menunjukkan adanya senyawa flavon, warna Merah Tua menunjukkan adanya senyawa flavonol atau flavonon, warna hijau sampai Biru menunjukkan adanya senyawa aglikon atau glikosida.

Hasil Skrining Fitokimia dapat dilihat pada gambar 3 dibawah ini

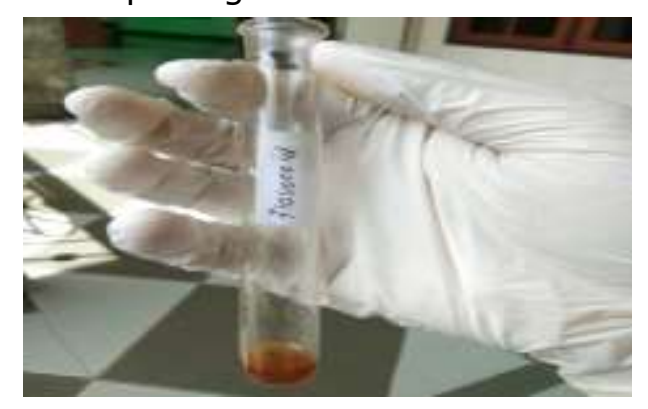

Gambar 1. Uji Flavonoid 


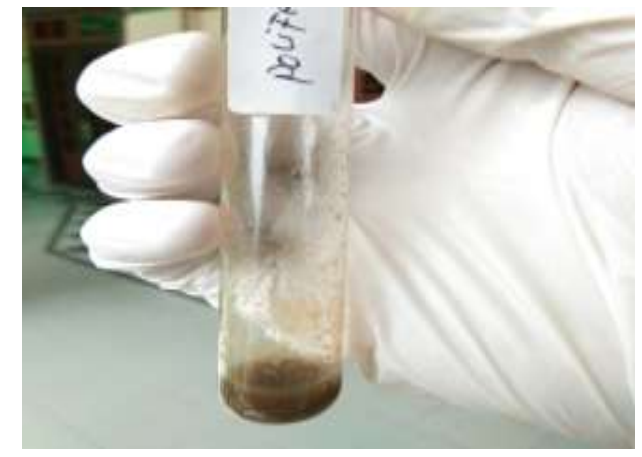

Gambar 2. Identifikasi Polifenol

Uji polifenol diperoleh hasil positif dengan penambahan $\mathrm{FeCl} 3$ terbentuk warna larutan Biru Tua, Biru kehitaman atau hitam kehijauan. Hasil Skrining Fitokimia dapat dilihat pada gambar 3 di bawah ini. Uji Polifenol

b. Identifikasi Sapponin

Identifikasi saponin dilakukan dengan memasukkan ekstrak uji kedalam tabung reaksi, ditambahkan $10 \mathrm{ml}$ air panas, didinginkan dan kemudian dikocok kuat-kuat selama 10 detik, terbentuk buih yang menetap selama tidak kurang dari 10 menit setinggi $1-10 \mathrm{~cm}$, penambahan $\mathrm{HCl} 2 \mathrm{~N}$ buih tidak hilang (Dewi Dkk, 2016). Hasil Skrining Fitokimia dapat dilihat pada gambar 3 dibawah ini.

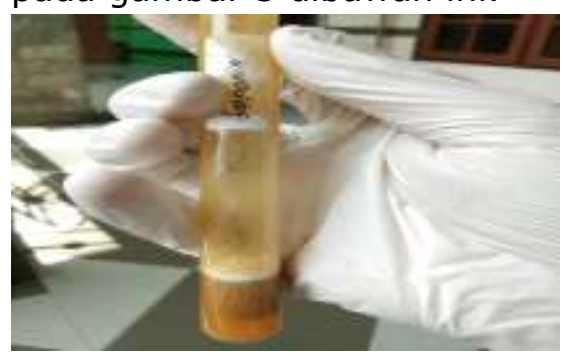

Gambar 3. Uji Saponin
Hasil Evaluasi Sediaan Masker Pelembab Wajah Ekstrak BungaKecombrang(Blanko,Konsentra si5\%dan Konsentrasi 10\%)
Hasil uji kelembaban kulit wajah dari sediaan Masker pelembab yang mengandung sediaan

maker pelembab wajah, kekuatan kelembaban kulit dari setiap responden berbeda-beda dipengaruhi oleh beberapa faktor diantaranya cuaca yang mempengaruhi suhu badan responden sehingga memicu responden berkeringat atau bahkan kering. Hasil uji responden dapat dilihat pada table 4 di bawah ini.

\begin{tabular}{lcccc}
\hline & & \multicolumn{3}{c}{ Persentase (\%) Kadar } \\
\cline { 3 - 5 } No & Sukarelaw & \multicolumn{3}{c}{ Air } \\
\cline { 3 - 5 } & an & $(-)$ & $(+)$ & $(+)$ \\
& & EKS & EKC & EKC \\
& & & $5 \%$ & $10 \%$ \\
1 & I & 37,8 & 44,6 & 53,3 \\
2 & II & 46,9 & 52,7 & 64,0 \\
3 & III & 36,2 & 57,5 & 60,6 \\
4 & IV & 41,8 & 52,7 & 59,1 \\
5 & V & 35,6 & 40,0 & 42,9 \\
6 & VI & 34,6 & 38,4 & 40,0 \\
Nilai Rata-Rata & 78,81 & 41,65 & 46,65 \\
\hline
\end{tabular}

Tabel 4. Uji Responden Sediaan

Organoleptis yang meliputi bentuk, bau dan warna sediaan masker dari berbagai konsentrasi sediaan (Blanko, 5\% dan 10\%). Sediaan masker pelembab kulit wajah memiliki nilai kelembaban yang lebih relatif dimana semakin tinggi konsentrasi sediaan maka akan semakin tinngi pula efektivitas sediaan untuk melembabkan kulit wajah.

\section{KESIMPULAN}

Berdasarkan hasil penelitian yang telah dilakukan dapat disimpulkan bahwa:

1. Sediaan masker pelembab wajah yang mengandung ekstrak Bunga kecombrang (Etlingera elatior) dapat dijadikan sebagai sediaan masker wajah.

2. Sediaan masker pelembab wajah memiliki kestabilan dari segi Organoleptis yang meliputi bentuk, bau dan warna sediaan 
Received: 30 Maret 2020 :: Accepted: 29 April 2019 :: Published: 30 April 2020

masker dari berbagai konsentrasi sediaan (Blanko, 5\% dan 10\%).

3. Sediaan masker pelembab kulit wajah memiliki nilai kelembaban yang lebih relatif dimana semakin tinggi konsentrasi sediaan maka akan semakin tinngi pula efektivitas sediaan untuk melembabkan kulit wajah.

4. Sediaan masker pelembab kulit wajah memiliki nilai kelembaban yang lebih relatif dimana semakin tinggi konsentrasi sediaan maka akan semakin tinngi pula efektivitas sediaan untuk melembabkan kulit wajah.

\section{DAFTAR PUSTAKA}

Adliani.(2012).FormulasiLipstikMenggu nakan Zat Warna dari Ekstrak Bunga Kecombrang (Etlingara elatior).Journal of Pharmaceutics and Pharmacology. Hal: 87-94.

Debi. (2018). Formulasi Sediaan Salep Antibakteri Menggunakan Ekstra Etanol Bunga Kecombrang (Etlingara elatior). Lubuk Pakam. Inkes Medistra.

Haraguchi. (1998). Antifungal Activity from A. Galanga and The Compotition For Incorporation Of Unsaturated Fatty Acid In cell Growth. Journal Of Plant Med. 62 (2) : 285-288.

Jackie. (2011). Penghantar Minyak Atsiri. Jakarta: Balai Pustaka.

Lestario.(2011). Kandungan Antosianin danIdentifikasi Antosianin. agritech 31(2) : 93-101.

Sanni.(2012).Pemanfaat Kecombrang Sebagai sirupUntuk Menambah Pendapatan Keluarga di Desa Minanga.Kab. Mamasa. Skripsi Makassar. FT-UNM.

Tarmizi.(2010).Kecombrang.http://tar miziblog.blogspot.com./2011/04/ Kecombrang.
Maimulyanti, Askal. (2015). Chemical composition, phytochemical and antioxidant activity from extract of Etlingera elatior flower from Indonesia.

http://www.phytojournal.com/arc hives/2015/vol3issue6/PartE/4-134.1.pdf. 